International Journal of Zoological Investigations

Contents available at Journals Home Page: www.ijzi.net

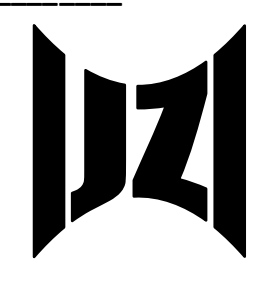

ISSN: 2454-3055

\title{
Impact of Methoprene Against the Egg Biochemistry of Rice Moth, Corcyra cephalonica Staint. (Lepidoptera: Pyralidae)
}

Tiwari S. K.

Department of Zoology, D.D.U. Gorakhpur University, Gorakhpur - 273009, India

Received: $17^{\text {th }}$ November, 2020

Accepted: $28^{\text {th }}$ December, 2020

Published online: $31^{\text {st }}$ December, 2020

https://doi.org/10.33745/ijzi.2020.v06i02.017

\begin{abstract}
Exposure of first instar larvae of rice moth, Corcyra cephalonica to the sublethal concentrations i.e. 4, 8 and $12 \mathrm{ppm}$ of methoprene caused dose-dependent alterations in the biochemical constituents of the eggs (laid within $24 \mathrm{~h}$ of mating by different crosses involving one or the other or both sexes emerged from treated culture). Such biochemical changes in eggs might lead to impairment of embyonic and post-embryonic growth and development of this pest, and hence, evolution of a new generation of this lepidopterous pest for the eventual establishment on stored cereals and cereal commodities can be considerably restricted.
\end{abstract}

Keywords: Corcyra cephalonica, Methoprene, Egg, Biochemistry, Growth, Development

Citation: Tiwari S.K.: Impact of methoprene against the egg biochemistry of rice moth, Corcyra cephalonica Staint. (Lepidoptera: Pyralidae). Intern. J. Zool. Invest. 6 (2): 366-382, 2020.

https://doi.org/10.33745/ijzi.2020.v06i02.017

\section{Introduction}

The rice moth, Corcyra cephalonica Staint. is a notorious pest of stored cereals and cereal commodities in Asia, Africa, North America, Europe and other tropical and sub-tropical regions of the world. Its larval stages cause serious damage to rice, gram, sorghum, maize, groundnut, cotton seeds, peanuts, linseeds, and milled products (Ayyar, 1919; Chittenden, 1919; Atwal, 1976; Piltz, 1977).
In recent years, there has been great concern over the toxicity of pesticides on nontarget organisms and the environment. The use of conventional organic insecticides to control insect pests have given rise to problems of the proliferation of resistance and accumulation of residues in the environment with adverse ecological effects due to non-biodegradability, biomagnification and 
toxicity to non-target organisms (Hoffmann and Lorenz, 1997).

Thus, there is a need of new alternatives to traditional insecticides used in stored product pest management (Mbata and Philips, 2001; Arthur and Philips, 2003). In the search of safer insecticides technologies i.e. more selective modes of action and reduced risks for non-target organisms and the environment, progress has been made with the development of natural and synthetic compounds capable of interfering with process of growth, development and metamorphosis of the target insects (Smet et al., 1989, 1991; Oberlander et al., 1997). In this regard, the insect growth regulators (IGRs) (Fox, 1990), which mimic insect's hormone and regulate the insect population through the disruption of moulting and metamorphosis (Williams, 1956; Oberlander et al., 1997) have captured the interest of stored-product entomologists. IGRs have generally little mammalian toxicity, specific to insects and degrade rapidly in the environment (Kostyukovsky et al., 2000; Ghasemi et al., 2010), therefore, considered as reduced risk insecticides and are often exempted from tolerance requirements of regulatory agencies. They are superior in several aspects to the usual insecticides as, due to its rapid degradation they do not affect beneficial parasites and predators (Fox, 1990) and have a wide spectrum activity on economically important pest species (Menn et al., 1981). Generally the insects do not develop resistance to IGRs (El-Ibrashy, 1970; Moreno et al., 1992; Degheele et al., 1993).

$\mathrm{JH}$ acts on so many aspects of insect reproduction that it can just be called a master regulator of the "female reproduction syndrome". In addition to its central role in oogenesis, JH affects dispersal and flight activity, calling behaviour, post-copulatory changes in female behavior, oviposition behaviour and follicular development (Ahmed et al., 2020).

The objective of the present study is to investigate the influence of methoprene on the internal biochemistry of eggs. This knowledge in turn, is likely to generate new insights into devising ways and means for controlling Corcyra cephalonica, by disrupting its embryonic and post-embryonic growth, development, reproductive behaviour and metabolic framework so that evolution of a new generation of this pest for the eventual establishment on stored cereals and cereal products can be considerably restricted.

\section{Materials and Methods}

Corcyra cephalonica Staint. adults were obtained from already existing laboratory stock culture maintained on normal dietary medium composed of coarsely ground jowar, Sorghum vulgare mixed with $5 \%(\mathrm{w} / \mathrm{w})$ powdered yeast inside large glass containers (150 $\mathrm{mm}$ diameter, $200 \mathrm{~mm}$ height) at temperature $26 \pm 1 \mathrm{C}$, relative humidity (R.H.) $93 \pm 5 \%$ and a light regime of $12 \mathrm{~h}$ light and $12 \mathrm{~h}$ darkness. Such a standard culture was maintained throughout the year.

From the above culture, whenever needed, newly emerged males and females were transferred to oviposition glass chambers (35 $\mathrm{mm}$ diameter, $200 \mathrm{~mm}$ height). Since, $C$. cephalonica individuals do not feed during their adult stage, no food was provided to them during their confinement in these vessels. Eggs laid by the females were collected and then placed in glass chambers (consisting of $250 \mathrm{ml}$ beakers) with the help of zero number camel hair brush for hatching. 
Methoprene $\left(\mathrm{C}_{19} \mathrm{H}_{34} \mathrm{O}_{3}\right)$; Isopropyl (2E, 4E)- 11- methoxy - 3, 7, 11 trimethyl - 2 - 1, 4 dodecadienoate; a juvenile hormone analogue, P-157N, Lot 18828, was obtained from AccuStandard, New Haven, CT06513, USA and used throughout the investigation.

Chemical structure of methoprene (Isopropyl (2E, 4E)-11-methoxy-3, 7, 11 trimethyl $-2-1,4$ dodecadienoate):

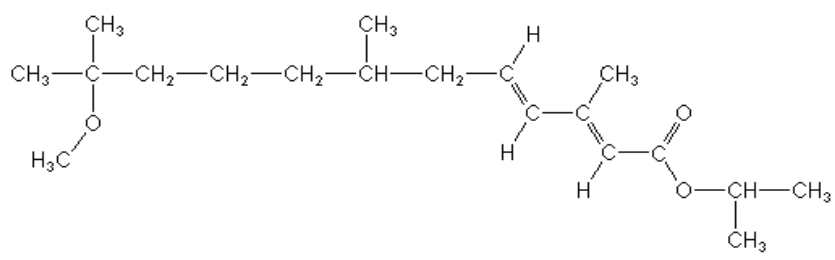

Preparation of different concentrations i.e. $2,4,8,12,16,20$ and $24 \mathrm{ppm}$ of methoprene in dietary media, evaluation of toxic effects of these concentrations at different life stages of C. cephalonica, amount of methoprene consumed ( $\mu \mathrm{g} / \mathrm{larva})$ at each concentration of methoprene have been reported by Tripathi and Tiwari (2015).

For biochemical estimations, out of various concentrations of the methoprene mentioned above only such concentrations i.e. sub-lethal (4, 8 and $12 \mathrm{ppm})$ were selected, which allowed the larvae to survive, develop and emerge as adult but caused considerable effect in the internal biochemistry of the eggs that could be easily detected and assessed to prove the effectiveness of hormonal control measures against this lepidopterous pest.

For such purpose, freshly hatched larvae were allowed to feed on a normal dietary medium (kept inside $250 \mathrm{ml}$ beakers) for 4 days. On the fifth day, 25 first instar larvae were transferred to each similar rearing chambers containing dietary medium mixed with 4,8 and $12 \mathrm{ppm}$ concentrations of methoprene and were allowed to complete their life-cycle and just after emergence, the males and females were collected and used for mating experiments. For this purpose, four types of crosses were made as following:

1. Normal male x Normal female (serving as control)

2. Treated male $x$ Normal female

3. Normal male $\mathrm{x}$ Treated female

4. Treated male $x$ Treated female

(Treated male and treated female refers to the male and female moths emerged from treated food).

These pairs were allowed to mate and lay eggs in the oviposition chambers $(35 \mathrm{~mm}$ diameter, $200 \mathrm{~mm}$ height glass tubes) separately. At each cross of each concentration, six pairs of males and females (each pair in separate mating/oviposition chamber) were kept for experimentation.

The eggs laid within $24 \mathrm{~h}$ of mating by the females of all the four crosses (i.e. Normal male x Normal female, Treated male x Normal female, Normal male $x$ Treated female and Treated male x Treated female) were collected separately for their biochemical estimations.

The entire programme of biochemical estimation includes the quantitative measurement of total protein, total free amino acids, nucleic acids and glycogen levels and the activity of acid and alkaline phosphatases of eggs laid within $24 \mathrm{~h}$ of mating by the females of all the four crosses (i.e. Normal male x Normal female, Treated male x Normal female, Normal male $x$ Treated female and Treated male x Treated female).

The methods used for the analysis of various biochemical constituents are as follows: 
The total protein in eggs was measured according to the method of Lowry et al. (1951) using bovine serum albumin as standard. Total free amino acids was determined according to the method of Spies (1957) using glycine solution as standard. Deoxyribonucleic acid (DNA) and ribonucleic acid (RNA) levels in eggs of $C$. cephalonica were estimated according to the method of Schneider (1957). Diphenylamine reagent was used for DNA estimation while orcinol reagent was used for RNA estimation. Glycogen was estimated according to the method of Van der Vies (1954) by using anthrone reagent. Acid and alkaline phosphatase activities in eggs were determined according to the method of Andersch and Szcypinski (1947) as modified by Bergmeyer (1967) using p-nitrophenylphosphate as substrate.

Results were expressed as the mean \pm SE of six replicates. Significant differences between treatment groups, in order to show dose-dependence, were determined by one way analysis of variance $(\mathrm{P}<0.001$ to $\mathrm{p}<$ 0.05 ) by using StatPlus $\AA$ version 2009. Student's t-test was applied to determine the significant differences between the corresponding treated groups and the controls $(\mathrm{P}<0.001$ to $\mathrm{p}<0.05)$.

\section{Results}

Exposure of sublethal concentrations i.e. 4, 8 and $12 \mathrm{ppm}$ of methoprene caused a significantly dose-dependent reduction in the levels of total protein, DNA, RNA, glycogen and in the activity of alkaline phosphatase and a significantly dose- dependent enhancement in the levels of total free amino acids and in the activity of acid phosphatase in the eggs (laid within $24 \mathrm{~h}$ of mating by different crosses involving one or the other or both sexes emerged from treated culture) of $C$. cephalonica (Tables 1-7).

The total protein content in the eggs obtained from control cross (normal males and normal females), was recorded to be 1.80 $\pm 0.15 \mu \mathrm{g} /$ egg (Table 1). The maximum decrease in total protein level in the eggs, collected from the crosses between treated males and normal females, normal males and treated females and treated males and treated females was recorded to be 57,51 and $36 \%$ of the control value, respectively following treatment with $12 \mathrm{ppm}$ concentration of methoprene (Table 1). Total protein levels in eggs, obtained from the crosses between treated males (i.e. emerged from treated cultures) and normal female, were reduced to $79 \%$ (1.42 $\pm 0.08 \mu \mathrm{g} / \mathrm{egg}$ ), 73\% (1.32 \pm 0.06 $\mu \mathrm{g} / \mathrm{egg})$ and $57 \%$ (1.02 $\pm 0.06 \mu \mathrm{g} / \mathrm{egg})$ of the control value following exposure of 4, 8 and 12 ppm concentrations of methoprene, respectively. The total protein levels in the eggs, collected from the crosses between normal males and treated females (i.e. emerged from treated cultures), were recorded to be $76 \%(1.36 \pm 0.05 \mu \mathrm{g} / \mathrm{egg}$ ), $66 \%$ (1.18 $\pm 0.04 \mu \mathrm{g} / \mathrm{egg})$ and 51\% (0.91 \pm 0.04 $\mu \mathrm{g} / \mathrm{egg}$ ) of control value following treatment with 4,8 and 12 ppm concentrations of methoprene, respectively.

The total protein content in the eggs, collected from the crosses between sexes both emerged from treated cultures was observed to be $69 \%$ (1.25 $\pm 0.07 \mu \mathrm{g} / \mathrm{egg}$ ), $53 \%$ (0.95 \pm $0.05 \mu \mathrm{g} / \mathrm{egg}$ ) and 36\% (0.64 $\pm 0.02 \mu \mathrm{g} / \mathrm{egg})$ of the control value following exposure of 4,8 
Table 1: Effects of methoprene on the total protein level ( $\mu \mathrm{g} / \mathrm{egg})$ in the eggs of C. cephalonica\#

\begin{tabular}{cccc}
\hline $\begin{array}{c}\text { Methoprene } \\
\text { concentration (ppm) }\end{array}$ & $\begin{array}{c}\text { Treated male } x \\
\text { Normal female }\end{array}$ & $\begin{array}{c}\text { Normal male } \mathrm{x} \\
\text { Treated female }\end{array}$ & $\begin{array}{c}\text { Treated male } \mathrm{x} \\
\text { Treated female }\end{array}$ \\
\hline 0.00 & $1.80 \pm 0.15$ & - & - \\
$($ control) & $(100)$ & $1.36 \pm 0.05^{\mathrm{c}}$ & $1.25 \pm 0.07^{\mathrm{b}}$ \\
4 & $1.42 \pm 0.08^{\mathrm{c}}$ & $(76)$ & $(69)$ \\
8 & $(79)$ & $1.18 \pm 0.04^{\mathrm{ba}^{\prime}}$ & $0.95 \pm 0.05^{\mathrm{ab}^{\prime}}$ \\
& $1.32 \pm 0.06^{\mathrm{c}}$ & $(66)$ & $(53)$ \\
12 & $(73)$ & $0.91 \pm 0.04^{\mathrm{ac}}$ & $0.64 \pm 0.02^{\mathrm{aa}^{\prime}}$ \\
& $1.02 \pm 0.06^{\mathrm{ab}^{\prime}}$ & $(51)$ & $(36)$ \\
& $(57)$ & & \\
\hline
\end{tabular}

\# Values are expressed as the mean $\pm \mathrm{SE}$ of six replicates; the values in the parentheses indicate the percentage change with control value taken as $100 \%$.

$\mathrm{a}, \mathrm{b}$ and $\mathrm{c}$ indicate significant differences, $\mathrm{P}<0.001, \mathrm{P}<0.01$ and $\mathrm{P}<0.05$, respectively compared with control; $\mathrm{a}^{\prime}, \mathrm{b}^{\prime}$ and $\mathrm{c}^{\prime}$ indicate significant difference, $\mathrm{P}<0.001, \mathrm{P}<0.01$ and $\mathrm{P}<0.05$, respectively from corresponding treated group when t-test was applied.

Analysis of variance showed that the response to the methoprene was dose-dependent $\mathrm{P}<0.001$.

and 12 ppm concentrations of methoprene respectively (Table 1).

Sublethal concentrations of methoprene caused a significantly dose-dependent $(\mathrm{P}<$ 0.001 ) enhancement in total free amino acids level in the eggs collected from the different crosses of C. cephalonica (Table 2). The total free amino acids level in the eggs, obtained from control cross (normal males and normal females) was recorded to be $0.96 \pm 0.05$ $\mu \mathrm{g} /$ egg. The maximum increase in total free amino acid levels in the eggs, collected from the crosses between treated males and normal females, normal males and treated females and treated males and treated females was recorded to be 125,127 and $131 \%$ of the control value, respectively following treatment with $12 \mathrm{ppm}$ concentration of methoprene. Total free amino acid levels in eggs, obtained from the crosses between treated males (i.e. emerged from treated cultures) and normal female, were increased to $106 \%$ (1.02 \pm 0.07 $\mu \mathrm{g} / \mathrm{egg}), 115 \%(1.10 \pm 0.07 \mu \mathrm{g} / \mathrm{egg})$ and $125 \%(1.20 \pm 0.06 \mu \mathrm{g} / \mathrm{egg})$ of the control value following treatment with 4,8 and $12 \mathrm{ppm}$ concentrations of methoprene, respectively.

The total free amino acids level in the eggs collected from the crosses between normal males and treated females (i.e. emerged from treated cultures), were recorded to be $113 \%$ 
Table 2: Effects of methoprene on the total free amino acids level ( $\mu \mathrm{g} / \mathrm{egg})$ in the eggs of $C$. cephalonica\#

\begin{tabular}{|c|c|c|c|}
\hline $\begin{array}{c}\text { Methoprene } \\
\text { concentration (ppm) }\end{array}$ & $\begin{array}{l}\text { Treated male } \mathrm{x} \\
\text { Normal female }\end{array}$ & $\begin{array}{l}\text { Normal male } \mathrm{x} \\
\text { Treated female }\end{array}$ & $\begin{array}{l}\text { Treated male } x \\
\text { Treated female }\end{array}$ \\
\hline $\begin{array}{c}0.00 \\
\text { (control) }\end{array}$ & $\begin{array}{l}0.96 \pm 0.05 \\
\quad(100)\end{array}$ & - & - \\
\hline 4 & $\begin{array}{l}1.02 \pm 0.07 \\
(106)\end{array}$ & $\begin{array}{c}1.08 \pm 0.05 \\
(113)\end{array}$ & $\begin{array}{l}1.11 \pm 0.07 \\
(116)\end{array}$ \\
\hline 8 & $\begin{array}{c}1.10 \pm 0.07 \\
(115)\end{array}$ & $\begin{array}{l}1.15 \pm 0.06^{c} \\
(120)\end{array}$ & $\begin{array}{l}1.18 \pm 0.05^{c} \\
(123)\end{array}$ \\
\hline 12 & $\begin{array}{l}1.20 \pm 0.06^{\mathrm{b}} \\
(125)\end{array}$ & $\begin{array}{c}1.22 \pm 0.06^{b} \\
(127)\end{array}$ & $\begin{array}{c}1.26 \pm 0.07^{\mathrm{b}} \\
(131)\end{array}$ \\
\hline
\end{tabular}

\# Values are expressed as the mean \pm SE of six replicates; the values in the parentheses indicate the percentage change with control value taken as $100 \%$.

$\mathrm{b}$ and $\mathrm{c}$ indicate significant difference, $\mathrm{P}<0.01$ and $\mathrm{P}<0.05$, respectively compared with control when $\mathrm{t}$ test was applied.

Analysis of variance showed that the response to the methoprene was dose-dependent $\mathrm{P}<0.001$.

$(1.08 \pm 0.05 \mu \mathrm{g} / \mathrm{egg}), 120 \%(1.15 \pm 0.06$ $\mu \mathrm{g} / \mathrm{egg})$ and $127 \%(1.22 \pm 0.06 \mu \mathrm{g} / \mathrm{egg})$ of control value when treated with 4,8 and 12 ppm concentrations of methoprene, respectively. The total free amino acid contents in the eggs obtained from the crosses between treated males and treated females (i.e. both sexes emerged from treated cultures) were observed to be $116 \%$ (1.11 \pm $0.07 \mu \mathrm{g} / \mathrm{egg}), 123 \%$ (1.18 $\pm 0.05 \mu \mathrm{g} / \mathrm{egg})$ and $131 \%(1.26 \pm 0.07 \mu \mathrm{g} / \mathrm{egg})$ of the control value following exposure of 4,8 and $12 \mathrm{ppm}$ concentrations of methoprene, respectively (Table 2).

Sublethal concentrations of methoprene caused a significantly dose-dependent $(\mathrm{P}<$ 0.01 ) reduction in DNA levels in the eggs collected from the different crosses of $C$. cephalonica (Table 3). The DNA levels in the eggs, obtained from control cross (normal males and normal females), was recorded to be $4.25 \pm 0.11 \mu \mathrm{g} / \mathrm{egg}$. The maximum decrease in DNA level in the eggs, collected from the crosses between treated males and normal females, normal males and treated females and treated males and treated females was recorded to be 63,54 and $40 \%$ of the control value respectively following exposure of 12 ppm concentration of methoprene. The DNA levels in eggs, obtained from the crosses between treated males (i.e. emerged from treated cultures) and normal females, were decreased to $89 \%$ (3.80 $\pm 0.10 \mu \mathrm{g} / \mathrm{egg}$ ), $69 \%$ $(2.92 \pm 0.08 \mu \mathrm{g} / \mathrm{egg})$ and $63 \%(2.69 \pm 0.08$ $\mu \mathrm{g} / \mathrm{egg})$ of the control value following treatment with 4,8 and $12 \mathrm{ppm}$ concentrations of methoprene, respectively. The DNA levels in the eggs, collected from the crosses between normal males and treated 
Table 3: Effects of methoprene on the DNA level ( $\mu \mathrm{g} / \mathrm{egg})$ in the eggs of C. cephalonica\#

\begin{tabular}{|c|c|c|c|}
\hline $\begin{array}{c}\text { Methoprene } \\
\text { concentration (ppm) }\end{array}$ & $\begin{array}{l}\text { Treated male } x \\
\text { Normal female }\end{array}$ & $\begin{array}{l}\text { Normal male } x \\
\text { Treated female }\end{array}$ & $\begin{array}{l}\text { Treated male } x \\
\text { Treated female }\end{array}$ \\
\hline $\begin{array}{c}0.00 \\
\text { (control) }\end{array}$ & $\begin{array}{l}4.25 \pm 0.11 \\
\quad(100)\end{array}$ & - & - \\
\hline 4 & $\begin{array}{c}3.80 \pm 0.10^{c} \\
(89)\end{array}$ & $\begin{array}{l}3.31 \pm 0.08^{\mathrm{a}} \\
(78)\end{array}$ & $\begin{array}{c}2.72 \pm 0.06^{a} \\
(64)\end{array}$ \\
\hline 8 & $\begin{array}{c}2.92 \pm 0.08 \mathrm{aa}^{\prime} \\
(69)\end{array}$ & $\begin{array}{c}2.87 \pm 0.06^{\mathrm{ab}^{\prime}} \\
(68)\end{array}$ & $\begin{array}{c}2.59 \pm 0.05^{\mathrm{a}} \\
(61)\end{array}$ \\
\hline 12 & $\begin{array}{c}2.69 \pm 0.08^{a} \\
(63)\end{array}$ & $\begin{array}{c}2.29 \pm 0.04 \mathrm{aa}^{\prime} \\
(54)\end{array}$ & $\begin{array}{c}1.70 \pm 0.03 \mathrm{aa}^{\prime} \\
(40)\end{array}$ \\
\hline
\end{tabular}

\begin{abstract}
\# Values are expressed as the mean \pm SE of six replicates; the values in the parentheses indicate the percentage change with control value taken as $100 \%$.

$\mathrm{a}, \mathrm{b}$ and $\mathrm{c}$ indicate significant differences, $\mathrm{P}<0.001, \mathrm{P}<0.01$ and $\mathrm{P}<0.05$, respectively compared with control; a' and $\mathrm{b}^{\prime}$ indicate significant difference, $\mathrm{P}<0.001$ and $\mathrm{P}<0.01$, respectively from corresponding treated group when t-test was applied.

Analysis of variance showed that the response to the methoprene was dose-dependent $\quad \mathrm{P}<0.001$.
\end{abstract}

females (i.e. emerged from treated cultures), were recorded to be $78 \% \quad 3.31 \pm 0.08$ $\mu \mathrm{g} / \mathrm{egg}), 68 \%(2.87 \pm 0.06 \mu \mathrm{g} / \mathrm{egg})$ and $54 \%$ $(2.29 \pm 0.04 \mu \mathrm{g} / \mathrm{egg})$ of control value when treated with 4,8 and $12 \mathrm{ppm}$ concentrations of methoprene, respectively. The DNA contents in the eggs obtained from the crosses between treated males and treated females (i.e. both sexes emerged from treated cultures), were found to be $64 \%(2.72 \pm$ $0.06 \mu \mathrm{g} / \mathrm{egg}), 61 \%(2.59 \pm 0.05 \mu \mathrm{g} / \mathrm{egg})$ and $40 \%(1.70 \pm 0.03 \mu \mathrm{g} / \mathrm{egg})$ of the control value following exposure of 4,8 and $12 \mathrm{ppm}$ concentrations of methoprene, respectively (Table 3).

Sublethal concentrations of methoprene caused dose-dependent $(P<0.01)$ reduction in RNA levels in the eggs, collected from the different crosses of C. cephalonica (Table 4). The RNA levels in the eggs obtained from control cross (normal males and normal females) was recorded to be $0.91 \pm 0.05$ $\mu \mathrm{g} /$ egg. The maximum decrease in RNA level in the eggs collected from the crosses between treated males and normal females, normal males and treated females and treated males and treated females, was recorded to be 60,54 and $45 \%$ of the control value, respectively following treatment with $12 \mathrm{ppm}$ concentration of methoprene. The RNA levels in eggs obtained from the crosses between treated males (i.e. emerged from treated cultures) and normal females, were decreased to $91 \%$ (0.83 $\pm 0.06 \mu \mathrm{g} / \mathrm{egg}$ ), $76 \%$ (0.69 \pm 0.05 $\mu \mathrm{g} / \mathrm{egg})$ and $60 \%(0.55 \pm 0.04 \mu \mathrm{g} / \mathrm{egg})$ of the control value following treatment with 4,8 
and $12 \mathrm{ppm}$ of methoprene, respectively. The RNA levels in the eggs, collected from the crosses between normal males and treated females (i.e. emerged from treated cultures), were recorded to be $85 \%(0.77 \pm 0.06$ $\mu \mathrm{g} / \mathrm{egg}), 69 \%(0.63 \pm 0.04 \mu \mathrm{g} / \mathrm{egg})$ and $54 \%$

Table 4: Effects of methoprene on the RNA level ( $\mu \mathrm{g} / \mathrm{egg})$ in the eggs of C. cephalonica\#

\begin{tabular}{cccc}
\hline $\begin{array}{c}\text { Methoprene } \\
\text { concentration (ppm) }\end{array}$ & $\begin{array}{c}\text { Treated male } x \\
\text { Normal female }\end{array}$ & $\begin{array}{c}\text { Normal male } \mathrm{x} \\
\text { Treated female }\end{array}$ & $\begin{array}{c}\text { Treated male } \mathrm{x} \\
\text { Treated female }\end{array}$ \\
\hline $\begin{array}{c}0.00 \\
\text { (control) }\end{array}$ & $(100)$ & - & - \\
4 & $0.83 \pm 0.06$ & $0.77 \pm 0.06$ & $0.70 \pm 0.05^{\mathrm{c}}$ \\
& $(91)$ & $(85)$ & $(76)$ \\
8 & $0.69 \pm 0.05^{\mathrm{c}}$ & $0.63 \pm 0.04^{\mathrm{b}}$ & $0.54 \pm 0.04^{\mathrm{ac}^{\prime}}$ \\
& $(76)$ & $(69)$ & $(59)$ \\
12 & $0.55 \pm 0.04^{\mathrm{a}}$ & $0.49 \pm 0.02^{\mathrm{ac}}$ & $0.41 \pm 0.03^{\mathrm{ac}^{\prime}}$ \\
& $(60)$ & $(54)$ & $(45)$ \\
\hline
\end{tabular}

\# Values are expressed as the mean \pm SE of six replicates; the values in the parentheses indicate the percentage change with control value taken as $100 \%$.

$\mathrm{a}, \mathrm{b}$ and $\mathrm{c}$ indicate significant differences, $\mathrm{P}<0.001, \mathrm{P}<0.01$ and $\mathrm{P}<0.05$, respectively compared with control; a' and c' indicate significant difference, $\mathrm{P}<0.001$ and $\mathrm{P}<0.05$, respectively from corresponding treated group when t-test was applied.

Analysis of variance showed that the response to the methoprene was dose-dependent $\quad \mathrm{P}<0.01$.

$(0.49 \pm 0.02 \mu \mathrm{g} / \mathrm{egg})$ of control value when treated with 4,8 and $12 \mathrm{ppm}$ of methoprene, respectively. The RNA content in the eggs, obtained from the crosses between treated males and treated females (i.e. both sexes emerged from treated cultures), were found to be $76 \%(0.70 \pm 0.05 \mu \mathrm{g} / \mathrm{egg}), 59 \%(0.54 \pm$ $0.04 \mu \mathrm{g} / \mathrm{egg})$ and $45 \%(0.41 \pm 0.03 \mu \mathrm{g} / \mathrm{egg})$ of the control value following exposure of 4,8 and $12 \mathrm{ppm}$ concentrations of methoprene, respectively (Table 4).

Sublethal concentrations of methoprene caused dose-dependent $(P<0.05)$ reduction in glycogen levels in the eggs collected from the different crosses of $C$. cephalonica (Table $5)$. The glycogen levels in the eggs obtained from control cross (normal males and normal females) was recorded to be $0.94 \pm 0.08$ $\mu \mathrm{g} /$ egg. The maximum decrease in glycogen levels in the eggs collected from the crosses between treated males and normal females, normal males and treated females and treated males and treated females was recorded to be 63,53 and $42 \%$ of the control value, respectively following exposure of $12 \mathrm{ppm}$ concentration of methoprene. It was observed that the glycogen level in eggs, collected from the crosses between treated males (i.e. emerged from treated culture) and normal females, were decreased to $80 \%(0.75 \pm 0.04$ $\mu \mathrm{g} / \mathrm{egg}$ ), $72 \%$ (0.68 $\pm 0.05 \mu \mathrm{g} / \mathrm{egg})$ and $63 \%$ $(0.59 \pm 0.03 \mu \mathrm{g} / \mathrm{egg})$ of the control value following treatment with 4,8 and $12 \mathrm{ppm}$ concentrations of methoprene, respectively. The glycogen level in the eggs collected from the crosses between normal males and treated females (i.e. emerged from treated culture) 
were recorded to be $75 \% \quad(0.70 \pm 0.04$ $\mu \mathrm{g} / \mathrm{egg}$ ), $67 \%$ (0.63 $\pm 0.03 \mu \mathrm{g} / \mathrm{egg}$ ) and 53\% $(0.50 \pm 0.02 \mu \mathrm{g} / \mathrm{egg})$ of control value when treated with 4,8 and 12 ppm concentrations of methoprene, respectively. The glycogen content in the eggs obtained from the crosses between treated males and treated females (i.e. both sexes emerged from treated culture) were found to be $69 \%(0.65 \pm 0.05 \mu \mathrm{g} / \mathrm{egg}$ ), $55 \%(0.52 \pm 0.04 \mu \mathrm{g} / \mathrm{egg})$ and $42 \%(0.39 \pm$
$0.03 \mu \mathrm{g} / \mathrm{egg}$ ) of the control value following exposure of 4,8 and 12 ppm methoprene concentrations, respectively (Table 5).

Sublethal concentrations of methoprene caused a significantly dose-dependent $(\mathrm{P}<$ 0.05) enhancement in the activity of acid phosphatase in the eggs collected from the different crosses of $C$. cephalonica (Table 6). The acid phosphatase activity in the eggs obtained from control cross (normal males

Table 5: Effects of methoprene on the glycogen level ( $\mu \mathrm{g} / \mathrm{egg})$ in the eggs of $C$. cephalonica\#

\begin{tabular}{|c|c|c|c|}
\hline $\begin{array}{c}\text { Methoprene } \\
\text { concentration (ppm) }\end{array}$ & $\begin{array}{l}\text { Treated male } x \\
\text { Normal female }\end{array}$ & $\begin{array}{l}\text { Normal male } x \\
\text { Treated female }\end{array}$ & $\begin{array}{l}\text { Treated male } x \\
\text { Treated female }\end{array}$ \\
\hline $\begin{array}{c}0.00 \\
\text { (control) }\end{array}$ & $\begin{array}{c}0.94 \pm 0.08 \\
(100)\end{array}$ & - & - \\
\hline 4 & $\begin{array}{c}0.75 \pm 0.04 \\
(80)\end{array}$ & $\begin{array}{c}0.70 \pm 0.04^{c} \\
(75)\end{array}$ & $\begin{array}{c}0.65 \pm 0.05^{c} \\
(69)\end{array}$ \\
\hline 8 & $\begin{array}{c}0.68 \pm 0.05^{c} \\
(72)\end{array}$ & $\begin{array}{c}0.63 \pm 0.03^{b} \\
(67)\end{array}$ & $\begin{array}{c}0.52 \pm 0.04^{\mathrm{a}} \\
(55)\end{array}$ \\
\hline 12 & $\begin{array}{c}0.59 \pm 0.03^{b} \\
(63)\end{array}$ & $\begin{array}{c}0.50 \pm 0.02^{\mathrm{ab}^{\prime}} \\
(53)\end{array}$ & $\begin{array}{c}0.39 \pm 0.03^{a c^{\prime}} \\
(42)\end{array}$ \\
\hline
\end{tabular}

\# Values are expressed as the mean \pm SE of six replicates; the values in the parentheses indicate the percentage change with control value taken as $100 \%$.

$\mathrm{a}, \mathrm{b}$ and $\mathrm{c}$ indicate significant differences, $\mathrm{P}<0.001, \mathrm{P}<0.01$ and $\mathrm{P}<0.05$, respectively compared with control; $\mathrm{b}$ ' and $c^{\prime}$ indicate significant difference, $\mathrm{P}<0.01$ and $\mathrm{P}<0.05$, respectively from corresponding treated group when $\mathrm{t}$-test was applied.

Analysis of variance showed that the response to the methoprene was dose-dependent $\mathrm{P}<0.05$.

Table 6: Effects of methoprene on the activity of acid phosphatase in the eggs of C. cephalonica\#

\begin{tabular}{cccc}
\hline $\begin{array}{c}\text { Methoprene } \\
\text { concentration (ppm) }\end{array}$ & $\begin{array}{c}\text { Treated male } \mathrm{x} \\
\text { Normal female }\end{array}$ & $\begin{array}{c}\text { Normal male } \mathrm{x} \\
\text { Treated female }\end{array}$ & $\begin{array}{c}\text { Treated male } \mathrm{x} \\
\text { Treated female }\end{array}$ \\
\hline $\begin{array}{c}0.00 \\
\text { control) }\end{array}$ & $\begin{array}{c}14.80 \pm 1.12 \\
(100)\end{array}$ & - & - \\
4 & $19.72 \pm 1.16^{\mathrm{c}}$ & $22.41 \pm 1.18^{\mathrm{a}}$ & $24.02 \pm 1.33^{\mathrm{a}}$ \\
& $(133)$ & $(151)$ & $(162)$ \\
8 & $23.22 \pm 1.44^{\mathrm{a}}$ & $25.66 \pm 2.04^{\mathrm{a}}$ & $27.75 \pm 1.64^{\mathrm{a}}$ \\
& $(157)$ & $(173)$ & $(188)$ \\
12 & $26.55 \pm 1.57^{\mathrm{a}}$ & $28.71 \pm 2.16^{\mathrm{a}}$ & $30.32 \pm 1.84^{\mathrm{a}}$ \\
& $(179)$ & $(194)$ & $(205)$
\end{tabular}

\# The activities are given as $\mu$ moles substrate hydrolyzed /30 minutes / mg protein and expressed as mean \pm SE of six replicates; the values in the parentheses are the percentage change with control value taken as $100 \%$.

$\mathrm{a}, \mathrm{b}$ and $\mathrm{c}$ indicate significant differences, $\mathrm{P}<0.001, \mathrm{P}<0.01$ and $\mathrm{P}<0.05$, respectively compared with control when t-test was applied.

Analysis of variance showed that the response to the methoprene was dose-dependent $\mathrm{P}<0.05$. 
and normal females), was recorded to be $14.80 \pm 1.12 \mu$ moles substrate hydrolyzed/30 $\mathrm{min} / \mathrm{mg}$ protein. The maximum increase in acid phosphatase activity in the eggs collected from the crosses between treated males and normal females, normal males and treated females and treated males and treated females was recorded to be 179,194 and $205 \%$ of the control value, respectively following exposure of 12 ppm concentration of methoprene. The acid phosphatase activities in the eggs, obtained from the crosses between treated males (i.e. emerged from treated culture) and normal females, were increased to $133 \%$ (19.72 \pm 1.16), $157 \%$ (23.22 \pm 1.44$)$ and $179 \%(26.55 \pm 1.57) \mu$ moles substrate hydrolyzed $/ 30 \mathrm{~min} / \mathrm{mg}$ protein of the control value following treatment with 4,8 and 12 ppm concentrations of methoprene, respectively. The acid phosphatase activities in the eggs collected from the crosses between normal males and treated females (i.e. emerged from treated culture), were recorded to be $151 \%$ (22.41 \pm 1.18$), 173 \%$ (25.66 \pm $2.04)$ and $194 \%(28.71 \pm 2.16) \mu$ moles substrate hydrolyzed $/ 30 \mathrm{~min} / \mathrm{mg}$ protein of control value when treated with 4,8 and 12 ppm concentrations of methoprene, respectively. The acid phosphatase activities in the eggs obtained from the crosses between treated males and treated females (i.e. both sexes emerged from treated culture) were found to be $162 \%$ (24.02 \pm 1.33$), 188 \%$ (27.75 \pm 1.64) and 205\% (30.32 \pm 1.84) $\mu$ moles substrate hydrolyzed $/ 30 \mathrm{~min} / \mathrm{mg}$ protein of the control value following exposure of 4, 8 and 12 ppm concentrations of methoprene, respectively (Table 6).
Sublethal concentrations of methoprene caused a significantly dose-dependent ( $\mathrm{P}<$ 0.05 ) reduction in the activity of alkaline phosphatase in the eggs collected from the different crosses of $C$. cephalonica (Table 7). The alkaline phosphatase activity in the eggs obtained from control cross (normal males and normal females), was recorded to be $39.52 \pm 2.14 \mu$ moles substrate hydrolyzed /30 $\mathrm{min} / \mathrm{mg}$ protein. The maximum decrease in alkaline phosphatase activity in the eggs collected from the crosses between treated males and normal females, normal males and treated females and treated males and treated females was recorded to be 66,59 and $40 \%$ of the control value, respectively following exposure of $12 \mathrm{ppm}$ concentration of methoprene. The alkaline phosphatase activities in the eggs obtained from the crosses between treated males (i.e. emerged from treated culture) and normal females, were decreased to $84 \%(33.15 \pm 1.81), 72 \%$ $(28.24 \pm 1.64)$ and $66 \%(26.11 \pm 1.42) \mu$ moles substrate hydrolyzed/30 $\mathrm{min} / \mathrm{mg}$ protein of the control value following treatment with 4,8 and 12 ppm concentrations of methoprene, respectively. The activities of alkaline phosphatase in the eggs collected from the crosses between normal males and treated females (i.e. emerged from treated culture), were recorded to be $76 \%(30.11 \pm 1.66), 66 \%$ (26.16 \pm 1.72$)$ and $59 \%(23.44 \pm 1.38) \mu$ moles substrate hydrolyzed /30 $\mathrm{min} / \mathrm{mg}$ protein of the control value when treated with 4, 8 and $12 \mathrm{ppm}$ concentrations of methoprene, respectively. The alkaline phosphatase activities in the eggs obtained from the crosses between treated 
males and treated females (i.e. both sexes

be $65 \%(25.86 \pm 1.62), 57 \%(22.52 \pm 1.11)$ emerged from treated culture), were found to and $40 \%(15.75 \pm 0.77) \mu$ moles substrate

Table 7: Effects of methoprene on the activity of alkaline phosphatase in the eggs of $C$. cephalonica

\begin{tabular}{|c|c|c|c|}
\hline $\begin{array}{l}\text { Methoprene } \\
\text { concentration (ppm) }\end{array}$ & $\begin{array}{l}\text { Treated male } x \\
\text { Normal female }\end{array}$ & $\begin{array}{l}\text { Normal male } x \\
\text { Treated female }\end{array}$ & $\begin{array}{l}\text { Treated male } x \\
\text { Treated female }\end{array}$ \\
\hline $\begin{array}{l}0.00 \\
\text { (control) }\end{array}$ & $\begin{array}{l}39.52 \pm 2.14 \\
(100)\end{array}$ & - & - \\
\hline 4 & $\begin{array}{l}33.15 \pm 1.81^{c} \\
(84)\end{array}$ & $\begin{array}{l}30.11 \pm 1.66^{b} \\
(76)\end{array}$ & $\begin{array}{l}25.86 \pm 1.62^{\mathrm{a}} \\
(65)\end{array}$ \\
\hline 8 & $\begin{array}{l}28.24 \pm 1.64 \mathrm{bd}^{\prime} \\
(72)\end{array}$ & $\begin{array}{l}26.16 \pm 1.72^{\mathrm{ac}^{\prime}} \\
(66)\end{array}$ & $\begin{array}{l}22.52 \pm 1.11^{\mathrm{a}} \\
(57)\end{array}$ \\
\hline 12 & $\begin{array}{l}26.11 \pm 1.42^{\mathrm{a}} \\
(66)\end{array}$ & $\begin{array}{l}23.44 \pm 1.38^{a} \\
(59)\end{array}$ & $\begin{array}{l}15.75 \pm 0.77 a^{\prime} \\
(40)\end{array}$ \\
\hline
\end{tabular}

\# The activities are given as $\mu$ moles substrate hydrolyzed /30 minutes / mg protein and expressed as mean \pm SE of six replicates; the values in the parentheses are the percentage change with control value taken as $100 \%$.

$\mathrm{a}, \mathrm{b}$ and $\mathrm{c}$ indicate significant differences, $\mathrm{P}<0.001, \mathrm{P}<0.01$ and $\mathrm{P}<0.05$, respectively compared with control; $\mathrm{a}^{\prime}$ and $\mathrm{c}^{\prime}$ indicate significant difference, $\mathrm{P}<0.001$ and $\mathrm{P}<0.05$, respectively from corresponding treated group when t-test was applied.

Analysis of variance showed that the response to the methoprene was dose-dependent $\quad \mathrm{P}<0.05$.

hydrolyzed/30 $\mathrm{min} / \mathrm{mg}$ protein of the control value following exposure of 4, 8 and $12 \mathrm{ppm}$ concentrations of methoprene, respectively (Table 7).

\section{Discussion}

The present investigation shows that when first instar larvae of C. cephalonica were exposed to sublethal concentrations i.e. 4, 8 and $12 \mathrm{ppm}$ of methoprene, certain biochemical constituents of eggs (laid within $24 \mathrm{~h}$ of mating by different crosses involving one or the other or both sexes emerged from treated culture.) were observed to exhibit significant quantitative variations. Earlier investigations revealed that sublethal concentrations i.e. 4,8 and 12 ppm of methoprene caused a significantly dosedependent reduction in the levels of total protein, DNA, RNA, glycogen and in the activity of alkaline phosphatase and a significantly dose-dependent enhancement in the levels of total free amino acids and in the activity of acid phosphatase in the gonadial tissues i.e. testis and ovaries of $C$. cephalonica (Tripathi, 2015).

Proteins are among the most complex of all known chemical compounds and also the most characteristic of living organisms. They serve as an important internal environmental factor for the metabolism, especially having a close relation with fat body, metamorphic hormone, trehalose and sex hormone during development and metamorphosis (Lee et al., 1981).

Methoprene suppresses egg production in insects by several mechanisms. In males JHAs disrupt spermatogenesis (Dumser and Davey, 1974) and functioning of accessory glands in 
some insect species and the degree to which the target tissue is affected differs with the species. In females, JHAs affect the development of oviducts (Koeppe et al., 1985), follicular growth (Koeppe et al., 1980), oocyte maturation (Koeppe et al., 1985) and functioning of accessory glands (Bodenstein and Sprague, 1959; Koeppe et al., 1985). JHAs treatment produced severe disorders in the ovaries of Tenebrio molitor including cell death in the germarium, resorption of oocytes in the previtellarium and vitellarium, formation of compound egg chambers and undue proliferation of follicular cells sometimes resulting in malformation of the whole ovaries (Metwally et al., 1972). These ovarian defects appear to be consequent with the changes in the course of cell proliferation, and $\mathrm{JH}$ compounds seemed to interfere with the cell division and differentiation (Metwally et al., 1972).

Earlier findings suggest that in pre-adult females of Sitophilus oryzae, hydroprene and R-20458 treatment prevented successful completion of vitellogenesis, formation of the germinal vesicle and karyosphere, and also blocked retraction of the oolemma and as a result the ovarioles remained atrophied and consequently no new generation was produced (Gupta and Mkhize, 1983). Diflubenzuron reduced oviposition in Tenebrio molitor, as a result of inhibition of ovarian DNA synthesis (Soltani-Mazouni and Soltani, 1994) and also due to interference with vitellogenesis via biochemical processes (Oberlander et al., 1975; Soltani et al., 1984; Soltani-Mazouni and Soltani, 1994). Fenoxycarb at 0.1-10 ppm concentration caused abnormal development of the male gonads in Ephestia kuehniella (Moreno, 1992) resulting into reduced fecundity of adults. Larval diet of triflumuron disrupted the testicular follicle in male Tribolium castaneum of both susceptible and resistant strains (Parween, 1996). Spermatids and sperm bundles in the treated males appeared to be abnormally large, and spermatogonia were few in number. When these treated males were allowed to mate with untreated females, egg viability was reduced and the effect was found to be dose-dependent. However, the male reproductive system of Tribolium castaneum was less affected than the female reproductive system (Parween, 1996). At higher doses of IGR treatment sterility may be permanent but at marginal doses the females may lay viable eggs at the later part of the oviposition period (Adan et al., 1994; Parween, 1996).

. JHAs have been observed to disturb the growth and maturation of the gonads in both sexes (Metwally et al., 1972; Soltani-Mazouni and Soltani, 1994, 1995; Parween, 1996) resulting in production of non-viable eggs.

In the present investigation, methoprene caused a significantly dose-dependent reduction in the level of total protein and a significantly dose-dependent enhancement in the levels of total free amino acids in the eggs, laid within $24 \mathrm{~h}$ of mating by different crosses involving one or the other or both sexes emerged from treated culture. It may be supposed that methoprene induced reduction in the levels of total protein in the ovaries of $C$. cephalonica (Tripathi, 2015), may be plausibly on account of poor synthesis of proteins and/or inhibition of amino acid incorporation into proteins in ovaries, which might be the possible reasons for the decreased level of 
total protein content in the eggs of the rice moth, C. cephalonica.

The high concentration of free amino acids is believed to play an important role with the predominant function of serving as units for protein synthesis (Buck, 1953) and taking part in other metabolic activities.

The enhancement in the total free amino acid levels in the eggs laid within $24 \mathrm{~h}$ of mating by different crosses involving one or the other or both sexes emerged from the treated culture, in the present investigation, may be due to methoprene induced inhibition of protein synthesis and/or inhibition of amino acid incorporation into protein in the ovaries (Tripathi, 2015) and ultimately into eggs.

DNA content provides an estimate of cell number whereas RNA content can be considered as an index of the capacity of organism for protein synthesis (Brachet, 1955; Lang et al., 1965).

In the present investigation, methoprene exposure caused a significantly dosedependent reduction in the levels of DNA and RNA in the eggs, laid within $24 \mathrm{~h}$ of mating by different crosses involving one or the other or both sexes emerged from the treated culture. Similar result was also reported in the eggs of Spodoptera litura exposed to an IGR, chlorfluazuron (Perveen, 2012). IGRdiflubenzuron inhibited ovarian DNA synthesis resulting into reduced oviposition in Tenebrio molitor (Soltani-Mazouni and Soltani, 1994) and also due to interference with vitellogenesis via biochemical processes (Oberlander et al., 1975; Soltani et al., 1984; Soltani-Mazouni and Soltani, 1994). It may be concluded that methoprene inhibits ovarian
DNA synthesis that resulted into reduced level of DNA and RNA in gonads of this pest (Tripathi, 2015) and consequently in the eggs in the present investigation.

Carbohydrates are one of the most essential biochemical constituents of insect tissues, many of which support optimum growth, development, reproductive activity and survival of individual species (Chefurka, 1959; Kilby, 1963; Wyatt, 1967; Friedman, 1970).

Glycogen can be synthesized also in the ovary itself, from haemolymph trehalose as major source (Yamashita and Hasegawa, 1985). Engles (1966) and Engles and Bier (1967) have reported that by applying $\mathrm{H}^{3}$ histidine at various stages of vitellogenesis in honey bee, Apis mellifica and Musca domestica L., the carbohydrate incorporation occurred primarily during later stages of oocyte maturation. They are of the opinion that the glycogen synthetase, essential for glycogen synthesis, does exist in inactive form in the earlier stages of oocyte maturation. With the help of radioautography, Ramamurty (1968) has also noticed almost similar findings and proposed that the nurse cells and follicle cells of ovaries of scorpion fly, Panorpa communis do not supply glycogen to the oocyte. But follicle cells have been reported to be the source of glycogen in the ovaries of Bombus (Palm, 1948) and honey bee (Bier, 1954). Engles and Drescher (1964) have observed that the labelled carbohydrate appeared in the oocyte within three minutes of application of $\mathrm{H}^{3}$ glucose, in case of Apis mellifica. This rapid uptake of glucose further suggests that it is the oocyte itself which is involved in carbohydrate synthesis. Blood glucose has also been reported to be utilized in the 
glycogen synthesis by the oocytes (Bonhag, 1956; Ramamurty, 1968).

Methoprene, in the present investigation, caused a significantly dose-dependent reduction in glycogen content in the eggs laid within $24 \mathrm{~h}$ of mating by different crosses involving one or the other or both sexes emerged from treated culture. It may be concluded that, in the present investigation, methoprene affects the synthesis of glycogen in the oocytes by hampering the activity of glycogen synthetase and/or by blocking the passage of raw materials for glycogen synthesis to the oocytes which results in the reduced levels of glycogen in the eggs. Similar opinion has also been suggested by Engles and Bier (1967) for the reduction of glycogen level by radioisotopic studies in Apis mellifica and Musca domestica L.

Acid phosphatase plays a significant role in catabolism, pathological necrosis, autolysis and phagocytosis (Abou Donia, 1978; Aruna et al., 1979). It has also been reported to have proteolytic action (Moczon, 1976) and helps in energy liberating processes (Dalela et al., 1978). Alkaline phosphatase is involved in the transport of metabolites across the cell membranes (Danielli, 1952; Vorbrodt, 1959), synthesis of certain enzymes (Sumner, 1965), protein synthesis (Pilo et al., 1972), secretory activity (Ibrahim et al., 1974) and spermatogenesis (Pavlikova and Repas, 1975), hydrolysis of phosphomonoesters under the alkaline condition (Miao, 2002). Both the enzymes (acid and alkaline phosphatases) have been shown to be associated with insect development, especially in relation to nutrition and egg maturation (Tsumuki and Kanehisa, 1984).
In the present study, it was observed that sublethal concentrations of methoprene caused a significantly dose-dependent enhancement in the activity of acid phosphatase and a significantly dosedependent reduction in the activity of alkaline phosphatase in the eggs laid within $24 \mathrm{~h}$ of mating by different crosses involving one or the other or both sexes emerged from the treated culture of $C$. cephalonica.

JHA induces cell proliferation of the gonads that results into significant enhancement in the activity of acid phosphatase in the testes and ovaries of insects as reported in case Gryllotalpa gryllotalpa (Mandal, 1982), milkweed bug, Oncopeltus fasciatus (Beel and Feir, 1977) and Chrysocoris stolli (Saha et al.,1985). Similar results have also been observed in testes, ovaries and eggs of $C$. cephalonica following exposure of fenoxycarb (Singh, 2015) and methoprene (Tripathi, 2015).

It may be assumed that in this study enhancement in the activity of acid phophatase and reduction in the activity of alkaline phosphatase in the eggs may be due to methoprene induced cell proliferation in the ovaries of this insect.

\section{Conclusion}

On the basis of the overall findings it may be concluded that methoprene exposure, in the present investigation, disrupts the egg biochemistry of $C$. cephalonica, which might lead to impairment of embyonic and postembryonic growth and development of this pest, and hence, evolution of a new generation of this lepidopterous pest for the eventual establishment on stored cereals and cereal commodities can be considerably restricted. 


\section{Acknowledgement}

Author is highly grateful to $\mathrm{M} / \mathrm{s}$ AccuStandard, New Haven, CT 06513, USA for the supply of the juvenile hormone analogue (methoprene) P$157 \mathrm{~N}$, Lot 18828.

\section{References}

Abou Donia, M B. (1978) Increased acid phosphatase activity in hens following an oral dose of leptophos. Toxicol Lett. 2: 199-203.

Adan A, Estal P D, Budia F, Narco V, Jacas J and Vinuela E. (1994) Effects of hexaflumuron on the fecundity and fertility of Tribolium castaneum Herbst (Coleoptera: Tenebrionidae). Bol Sanid Veg Plagas 20: 371-377.

Ahmed TH, Saunders TR, Mullins D, Rahman MZ and Zhu J. (2020) The juvenile hormone receptor Methoprene-tolerant is involved in the sterilizing effect of pyriproxyfen on adult Aedes aegypti mosquitoes. https://doi.org/10.1101/2020.05.31. 126508.

Andersch MA and Szcypinski AJ. (1947) Determination of alkaline phosphatase in serum with pnitrophenylphosphate. In: Methods in Enzymatic Analysis. (ed.) Bergmeyer, U.H., Academic Press, New York, pp. 571-57.

Arthur FH and Phillips TW. (2003) Stored-product insect pest management and control. In: Food Plant Sanitation. (eds.) Hui, Y.H., B.L. Bruinsma, J.R. Gorham, W.K. Nip, P.S. Tong and P. Ventresca, Marcel Dekker, New York, 341-358.

Aruna P, Chetty C S, Naidu RC and Swami K S. (1979) Acid phosphatase activity in Indian apple snail, Pila globosa (Swainson) during aestivation and starvation stress. Proc Indian Acad Sci. 88 B: 363-365.

Atwal AS. (1976) Agricultural Pests of India and SouthEast Asia. Kalyani Publishers, Delhi, pp. 502.

Ayyar TVR. (1919) Some insects recently noticed as injurious in South India. In: Rep. Proc. Third Entomol. Meet. (ed.) Fletcher, T.B., Vol. 1, Pusa, Superintendent Government Printing, Calcutta, pp. 314-328.

Beel C and Feir D. (1977) Effect of juvenile hormone on acid phosphatase activity in six tissues of the milkweed bug. J Insect Physiol. 23: 761-763.

Bodenstein D and Sprague JB. (1959) The developmental capacities of the accessory sex glands in Periplaneta americana. J Exp Zool. 142: 177-201.

Bonhag P F. (1956) The origin and distribution of periodic acid-Schiff-positive substances in the oocyte of the earwig, Anisolabis maritima (Gene). J Morphol. 99: 433-463.

Brachet J. (1955) In: The Nucleic Acids. (eds.) Chargaff, E. and J.N. Davidson, Vol. 2, Academic Press, New York, pp. 475-419.

Buck J B. (1953) The internal environment in regulation and metamorphosis. In: Insect Physiology. (ed.) Roeder K, Wiley, New York, pp. 191-217.

Chefurka W. (1959) Glucose metabolism in insects. In: Biochemistry of Insects, Symposium XII of the IV Int. Congress Biochem. (ed.) Levenbook, L, Pergamon Press.

Chittenden FH. (1919) The rice moth. U. S. Department of Agricultural, Bulletin No. 783. Washington (Govt. Print. Off.), pp. 15.

Dalela RC, Bhatnagar MC and VermA SR. (1978) Histochemical studies on the effect of rogor and thiodon on the activity of acid phos phatase in liver, muscles and kidney of Chana gachua. Indian J Exp Biol. 16: 1099-1102.

Danielli JF. (1952) Structural factors in cell permeability and secretion. In: Structural Aaspects of Cell Physiology. Symp. Society Experimental Biology, Vol. 6, Academic Press, Inc., New York, pp. 1-15.

Degheele D, Yi SX and Bai C. (1993) Toxicity of benzoylphenylureas to the African armyworm Spodoptera exempta (Walker). Crop Prot. 12: 35-38.

Dumser JB and Davey KG. (1974) Endocrinological and other factors influencing testis development in Rhodnius prolixus. Can J Zool. 52: 1011-1022.

El-Ibrashy MT. (1970) Insect hormones and analogues, chemistry, biology and insecticidal potencies. Z Angew Entomol. 66: 113-114.

Engles W. (1966) Der zeitliche ablauf von protein- und kohlenhydratsynthesen in der oogenase bei Apis mellifica L. Zool Anz Suppl. 29: 243-251.

Engles W and Bier K. (1967) Zur glycogenspeicherung wahrend oogenase und ihrer vorzeitiger auslosung durch blockiering der RNS-versorgung (untersuchungen an Musca domesticus L.). Wilhelm Roux Arch Entwick. -Mech Org. 158: 64-88.

Fox P. (1990) Insect Growth regulators. P.J.B. Publication Limited. Richmond. U.K., pp. v + 108.

Friedman S. (1970) Chemical Zoology. (eds.) Florkin, M. and B.T. Scheer, Vol. 5, Part A, Academic Press, New York, pp. 167-197. 
Ghasemi A, Sendi JJ and Ghadamyari M. (2010) Physiological and biological effect of Pyriproxifen on Indian meal moth Plodia Interpunctella (Hubner) (Lepidoptera: Pyralidae). J Plant Prot Res. 50: 416-422.

Gupta AP and Mkhize JM. (1983) Developmental and morphogenetic effects of two insect growth regulators (Hydroprene and R-20458) on the femal e rice weevil, Sitophilus oryzae (L.) (Coleoptera : Curculionidae). App Ent Zool. 18: 11-21.

Hoffmann KH and Lorenz MW. (1997) The role of ecdysteroids and juvenile hormones in insect reproduction. Trends Comp Biochem Physiol. 3: 1-8.

Ibrahim AM, Higazi MG and Demian ES. (1974) Histochemical localization of alkaline phosphatase activity in the alimantry tract of the snail, Marisa cornuarietis (L.). Bull Zool Soc Egypt. 26: 94-105.

Kilby B A. (1963) The biochemistry of the insect fat body. In: Advances in Insect Physiology. (eds.) Beam ent, J.W.L., J.E. Treherne and V.B. Wigglesworth, Vol. 1, Academic Press, London and New York, pp. 111-174.

Koeppe JK, Hobson K and Wellman SE. (1980). Juvenile hormone regulation of structural changes and DNA synthesis in the follicular epithelium of Leucophaea maderae. J Insect Physiol. 26: 229-240.

Koeppe JK, Fuchs M, Chen TT, Hunt LM, Kovalick GE and Briers T. (1985) The role of juvenile hormone in reproduction. In: Comprehensive Insect Physiology Biochemistry and Pharmacology. (eds.) Kerkut, L.I. and G.A. Gilbert, Vol. 8, Pergamon Press, Oxford, pp. 165-203.

Kostyukovsky M, Chen B, Atsmi S and Shaaya E. (2000) Biological activity of two juvenoids and two ecdysteroids against three stored product insects. Insect Biochem Mol Biol. 30: 891-897.

Lang CA, Lau HY and Jefferson DJ. (1965) Protein and nucleic acid changes during growth and aging in the mosquito. Biochem J. 95: 372-377.

Lee JJ, Shim JC and Lee KR. (1981) The effect of insecticides on haemolymph in the German cockroach, Blattela germanica L. Korean J Entomol. 11: 25-32.

Lowry OH, Rosenbrough NJ, Farr AL and Randall RJ. (1951) Protein measurement with the Folin phenol reagent. J Biol Chem. 193: 265-275.

Mandal S. (1982) Effect of juvenoid and allatec tomy on the biochemical components of gonads in Gryllotalpa gryllotalpa (Grllotalpidae: Orthoptera: Insecta). Proc Indian Nat Sci Acad. B48, No. 4: 486- 492.
Mbata GN and Phillips TW. (2001) Effects of temperature and exposure time on mortality of stored-product insects exposed to low pressure. J Econ Entomol. 94: 1302-1307.

Menn JJ, Henrick CA and Staal GB. (1981) Juvenoids: bioactivity and pros pects for insect management. In: Regulation for Insect Development and Behaviour. (ed.) Kloza, M, Inter. Conf. Karpacz, Poland, pp.735-748.

Metwally MM and Landa V. (1972) Sterilization of the khapra beetle, Trogoderma granarium Everts, with juvenile hormone analogues. Z Angew Entomol. 72: 97-109.

Miao Y. (2002) Studies on the activity of the alkaline phosphatase in the midgut of infected silkworm, Bombyx mori L. J Appl Entomol. 126: 138-142.

Moczon T. (1976) Inhibitory effect of pesticides on phosphatase, glucosidase and acetylcholinesterase activity in miracidium of Fasciola hepatica. Histochemical data. Bull Acad Pol Sci Ser Sci Biol. 24: 289-292.

Moreno J. (1992) Effect of the juvenile hormone analog fenoxycarb on the last larval instar of Ephestia kuehniella Zell. (Lep. Pyralidae). J Appl Entomol. 114: $118-123$

Oberlander H, Sower L and Silhacek DL. (1975) Mating behaviour of Plodia interpunctella reared on juvenile hormone treated diet. J Insect Physiol. 21: 681-685.

Oberlander H, Silhacek DL, Shaaya E and Ishaaya I. (1997). Current status and future perspectives of the use of insect growth regulators for the control of stored product insects. J Stored Prod Res. 33: 1-6.

Palm NB. (1948) Normal and pathological histology of the ovaries in Bombus Latr. (Hymenopt.). Opuscula Entomol Suppl. 7: 1-110.

Parween S. (1996) The effect of Triflumuron on malathion-susceptible (FSS II) and malathionresistant (CTC 12) strains of Tribolium castaneum Herbst. Ph.D. Thesis, University of Newcastle upon Tyne, UK, pp. 229.

Pavlikova D and Repas S. (1975) Comparative histochemical studies of changes in spermatogenesis and intertubular tissue at male sterility. Biol Bratisl. 30: 889-895.

Perveen F. (2012) Biochemical analyses of action of chlorfluazuron as reproductive inhibitor in Spodoptera litura. In: Insecticides-Advances in Integrated Pest Management. In Tech, Open Access Publisher, pp. 293-326.

Pilo B, Asnani MV and Shah RV. (1972) Studies on wound healing and repairs in pigeon liver. III. 
Histochemical studies on acid and alkaline phosphatase during the process. J Anim Morphol Physiol. 19: 205-212.

Piltz H. (1977) Corcyra cepha lonica (Staint.). In: Disease Pests and Weeds tropical crops. (eds.) Kranz, J., H. Schmutterer and W. Koch, Verlag Paul Parey, Berlin, Hamburg, pp. 439-440.

Ramamurty PS. (1968) Origin and distribution of glycogen during vitellogenesis dof the scorpion fly Panorpa communis. J Insect Physiol. 14: 1325-1330.

Saha LM, Mandal S and Choudhuri DK. (1985) Biochemical changes in testis and ovary of Chrysocoris stolli Wolf. after the application of juvenoid and ecdysterone. Rev Esp Fisiol. 41: 249-258.

Schneider WC. (1957) Determination of nucleic acids in tissues by pentose analysis. In: Methods in Enzymology. (eds.) Colowick, S.P. and N.O. Kaplan Vol. 3, Academic Press, New York, pp. 1154.

Singh A. (2015) Physiological and biochemical effects of fenoxycarb, a juvenile hormone analogue on the rice moth, Corcyra cephalonica Stainton (Lepidoptera: Pyralidae). Ph.D. Thesis, Department of Zoology, D.D.U. Gorakhpur University, Gorakhpur, India.

Smet H, Rans M and Loof A De. (1989). Activity of new juvenile hormone analogues on a stored food insect, Tribolium confusum (J. du Val) (Coleoptera: Tenebrionidae). J Stored Prod Res. 25: 165-169.

Smet H, Rans M and Loof ADe. (1991) Comparative effectiveness of insect growth regulators with juvenile hormone, anti-juvenile hormone and chitin synthesis inhibiting activity against several stored food insect pests. In: Proc. Fifth Int. Workng. Conf. Stored Prod. Prot., Bordeaux, (eds.) Fleurat-Lessard, F. and P. Ducom, Imprimerie du Médoc, Bordeaux, France, pp. 649-658.

Soltani N. (1984) Effects of ingested diflubenzuron on the longevity and the peritrophic membrane of adult mealworms (Tenebrio molitor L.). Pest Sci. 15: 221-225.

Soltani-Mazouni N and Soltani N. (1994) Diflubenzuron affected DNA synthesis in the ovaries of Tenebrio molitor. Invert Repro Dev. 25: 19-21.
Soltani N and Soltani-Mazouni N. (1995) Effect du diflurobenzuron en traitment in vivo et in vitro sur la morphometrie de l'ovarie de Tenebrio molitor. Med Fac Landbouww Univ Gent. 60: 961-968.

Spies JR. (1957) Colorimetric procedures for amino acids. In: Methods in Enzymology. (eds.) Colowick, S.P. and N.O. Kaplan, Academic Press, New York, pp. 464-471.

Sumner AT. (1965) The cytology and histochemistry of the digestive gland cells of Helix. Quarl J Microsc Sci. 106: 173-192.

Tripathi P. (2015) Effect of methoprene, an insect grow th regulator, on the reproductive biology of rice moth, Corcyra cephalonica Staint. (Lepidoptera: Pyralidae). Ph.D. Thesis, Department of Zoology, D.D.U. Gorakhpur University, Gorakhpur, India.

Tripathi, P and Tiwari SK. (2015) Influence of methoprene on the reproductive behaviour of the first instar larva of rice moth, Corcyra cephalonica Stainton(Lepido ptera: Pyralidae). Front Biol Life Sci. 3: 34-38.

Tsumuki H and Kanehisa K. (1984) Phosphatases in the rice stem borer, Chilo suppressalis Walker (Lepidoptera, Pyralidae): Some properties and changes of the activities during hibernation. Cryobiology 21: 177-182.

Van der Vies J. (1954) Two methods for the determination of glycogen in liver. Biochem J, 57: 410-416.

Vorbrodt A. (1959) The role of phosphatase in intracellular metabolism. Postepy Hig Med Dosw. 13: $200-206$.

Williams CM. (1956) The juvenile hormone of insects. Nature 178: 212-213

Wyatt GR. (1967) The biochemistry of sugars and polysaccharides in insects. Adv Insect Physiol. 4: 287-360.

Yamashita $O$ and Hasegawa K. (1985) Embryonic dipause. In: Comprehensive Insect Physiology, Biochemistry and Pharmacology. (eds.) Kerkut, G.A. and L.I. Gilbert, Vol.1, Pergamon Press, Oxford, pp. 407-434. 